\title{
AGROFORESTRY TECHNIQUES ON PEATLAND IN SABARU VILLAGE, PALANGKARAYA
}

\author{
Yanarita, Johanna M. Rotinsulu \\ Department of Forestry, Faculty of Agricultural \\ University of Palangka Raya, Palangka Raya, Central Kalimantan, Indonesia
}

Email: yanaritabaddak@gmail.com

\begin{abstract}
Central Kalimantan with an area of $15,356,400$ hectares have the degraded area of 4,636,890 hectares, some of which are peatlands. Peatlands are different from mineral lands or other organic lands. The chemical properties and characteristics of the peat including high acidity, low nutrient availability, and level of pyrite or sulfur should become the critical concerns for the success of land rehabilitation. One of the rehabilitation measures for degraded peatlands is by carrying out agroforestry techniques, the cropping patterns combining forest and agricultural crops that are mutually synergistic, with the goal of timber production in the long-term and crop production in the short term to meet the daily needs. The community development on agroforestry techniques on peatland in Sabaru Village, Palangkaraya, is one way to provide the insight to public to use lands to increase their income while improving and increasing the land productivity. The methods used in the agroforestry techniques in the village were the extension and training. The selected forest crop was meranti (Shorea Belangeran) and the perennial crops were petai (Parkia speciosa), mango (Mangifera indica) and rambutan (Niphelium lappaceum), while the agricultural crops were okra (Abelmoschus esculentus) and cayenne pepper (Capsicum frutescens), and the versatile crops turmeric (Curcuma domestica), lemongrass (Cymbopogon nardus), red ginger (Zingiber officinale Var. Rubrum Rhizoma), and kencur (Kaempferia galanga L.). The extension was performed by introducing the types of forest and agricultural crops, land preparation, planting techniques, and maintenance. The training was conducted by carrying out direct practices of agroforestry techniques, which created a pilot project on an area of 0.5 hectares. After 5 months, the results showed that Shorea Belangeran and Parkia speciosa had the growth percentage of $90 \%$. Although
\end{abstract}

the agricultural and versatile crops grew well, they were used only for everyday purposes.

Keywords: agricultural crop, crop, degraded land, demonstration plot, forest, rehabilitation

\section{INTRODUCTION}

In 2013, degraded lands in Indonesia covered an area of $27,294,842$ hectares, consisting of critical lands $(22,025,581 \mathrm{ha})$ and very critical lands $(5,269,260 \mathrm{ha})$. Of the total area, the highest figure of degraded lands in Sumatra, Java, Kalimantan, Maluku, and Papua regions was in South Sumatra $(3,886,062 \mathrm{ha})$, East Java $(608,913 \mathrm{ha})$, Central Kalimantan $(4,636,890 \mathrm{ha})$, East Nusa Tenggara $(1,041,688 \mathrm{Ha})$, and Papua $(1,076,699 \mathrm{ha})$, respectively. Meanwhile, the capability of land rehabilitation/ reforestation in 2013 only reached 105,656 ha (WALHI, 2015). The degraded lands had the environmental impacts (erosion, flooding, and drought) and economic impacts (reduction in income) to community (Simon, 1994).

The increase in degraded lands is the simultaneous unity among biophysical, socioeconomic and cultural conditions related to the utilization of land as a major production, and the implementation of policies that lack of sustainability consideration (Matatula, 2009). Therefore, in determining the control measures and approaching models, it is necessary to consider the representation of socio-cultural aspects and local community preferences. In order to obtain the technical bases for the approach and control of the degraded lands, it is also necessary to provide the synthesis technology that can bridge the interests of the community and the measures of land rehabilitation.

Palangka Raya is the capital city of Central Kalimantan with an area of $2,400 \mathrm{~km}^{2}$, equivalent to 3.6 times of the Jakarta area. The population in Palangka Raya is about 224,663 and the population density 92,067 per $\mathrm{km}^{2}$ (the city of Palangka Raya, 2010). Palangka Raya consists of 5 sub-districts 
divided into 30 villages. The livelihoods of the people are $67 \%$ in agriculture, services, and trade. In general, Palangka Raya has 3 (three) faces, namely urban, countryside, and forest faces. This condition gives particular challenges to the government of Palangka Raya in building the city, and carrying out the land rehabilitation program because the number of degraded lands in Central Kalimantan is very high.

The rehabilitation of degraded lands, by adopting a model that has been successful in other areas but is "forced" to be applied to the area with distinctive differences, is generally less successful (Foresta, H. De and G. Michon. 2000). The uniqueness of the area (site specific) along with the opportunities and challenges of local culture are the major concerns in developing the models of rehabilitation to be applied. Based on the analysis of the situation, there were several problems in Sabaru Village: (1) the community did not make a balance between the protection and conservation of land and water resources, (2) the diversity and uniqueness of the typical land (sandy peat) required specific rehabilitation treatment, and (3) the selection of commodities both perennial and seasonal crops (agricultural crops) did not meet the community needs.

The Community Development Activity carried out in Sabaru Village, Palangka Raya, was a model of land rehabilitation by developing agroforestry technology of agrisilviculture systems. The term of agroforestry technology of agri-silviculture systems in this case is the refinement of agroforestry practices already prevalent in the local communities through the intervention of a typical peat forest crops among seasonal crops. The forest crop intervention is intended to increase the productivity of degraded peatlands; to obtain the yield of seasonal crops (short-term) and timber (long-term). The area of Sabaru Village is largely degraded and infertile peatland. The land is composed of dust and sand materials, gravels and loose chunks, and in some places it is composed of quartz sand and clay, metamorphic rocks and granites. The land will be inundated in the rainy season, but be very dry during the dry season

The purposes of this community development activity were to develop agroforestry demonstration plots by implementing agroforestry techniques of agrisilviculture systems, namely a mixture of forest and agricultural crops, or versatile crops (multipurpose tree species), to improve the productivity of land, to increase community income by utilizing vacant lands or yards, and to rehabilitate degraded lands. This project is expected to provide more information about agroforestry techniques of agri-silviculture systems, which is intended not only to increase the value of product (timber) in the long term but also to protect and preserve the environment. Moreover, it also provides socioeconomic benefits to the community, like the forestry crops in the long term and agricultural crops in the short term.

\section{MATERIALS AND METHODS}

The methods used in this community development activity were extension and training. What conveyed in the extension was about the forest crops to be planted, the benefits of the crops, land management techniques, forest crop planting, agricultural crop planting, and versatile crop (multipurpose tree species) planting. The extension was delivered to two farmer groups in Sabaru Village. In order to strengthen the outputs of the extension, debriefing and discussion were conducted. The extension was the preparation before establishing the agroforestry demonstration plots for degraded peatland rehabilitation. The training was carried out by establishing agroforestry demonstration plots with agri-silviculture systems on the land (0.5 ha) owned by the farmer groups.

The equipment used in the training were hoes, machetes, shovels, wheelbarrows, dipper, buckets, manure, land forks and other agricultural tools. The materials used in the training were seedlings of (1) forest crops, namely meranti (Shorea Belangeran) and perennial crops like petai (Parkia speciosa), mango (Mangifera indica) and rambutan (Niphelium lappaceum), (2) agricultural crops, such as okra (Abelmoschus esculentus) and cayenne pepper (Capsicum frutescens), and (3) versatile crops, turmeric (Curcuma domestica), lemongrass (Cymbopogon nardus), red ginger (Zingiber officinale Var. Rubrum Rhizoma), and kencur (Kaempferia galanga L.)

\section{Training and Demonstration Plot Establishment}

The land for demonstration plots was 0.5 ha of degraded peatland or unproductive land, which belonged to the community. The 
work steps of agroforestry techniques of agriculture systems were as follows:

Given the limited time, the seedlings for perennial and forest crops were bought from the community's seedling nursery, which were then selected. For the seedlings of forest crop (meranti) and perennial crops (banana, mango and rambutan), the age of the crops were taken into account; they reached the age of one year or so and were ready to be planted. The seedlings of agricultural crops were purchased from store, or provided by the farmer groups, community, or market.

The soil tillage of unproductive degraded peatlands can be broken down into several activities, namely:

1. Clearing undergrowth, grasses and other vegetation growing on the land. The main objective of this work was to remove weeds from the planting field. The plants that were beneficial for the community and the protection of the area were not cut down.

2. Collecting litters that had been cut during the undergrowth clearing. The litters were burnt little by little and the burnt litters could be used to improve soil fertility.

3. Doing gebrus, the first soil tillage using a hoe to loosen the soil pores, and soften the soil surface to make it a good planting medium which was friable and loose with good aeration and able to reduce the potential growth of weeds to a minimum.

4. Making the arrays for forest and agricultural crops, started from the boundary of edge plants in the plots. The distance between the arrays for forest crops was 5 meters. Manure fertilizer was applied to improve the soil fertility.

5. Making the signs in places that needed ditches or terraces to ensure good systems of water drainage, erosion control, environmental protection, and maintenance of soil fertility.

Meranti was planted on the array with a spacing of $5 \times 5 \mathrm{~m}$. The perennial crops such as banana, mango and rambutan were also planted on the array with a spacing of $5 \times 5 \mathrm{~m}$. The forest crops were planted during rainy season, and the seedlings were sprinkled with water to keep the crop vigor in the field.
Meanwhile, the planting of agricultural crops was made to suit the field condition, with the main principle that the agricultural crops did not interfere with the forest crops, but instead became the stimulus for the forest crops when the maintenance was carried out. Agricultural crops required more maintenance than forest crops so when the maintenance (fertilizer, weeding, and pendangiran) was conducted, it also affected the growth of agricultural crops.

Once the forest and agricultural crop seedlings were planted, the routine maintenance activities were performed, such as watering, fertilizing, weeding and pendangiran, to make the crops grew well.

\section{RESULTS AND DISCUSSION}

\section{Extension}

The extension was carried out in the community house, attended by two farmer groups, namely the farmer groups of Indah Permai and Gemor Basir Jahan. Initially, the number of farmer group members to be given the extension was 20 people ( 10 farmers of each farmer group), but at the time of extension, the number of people participating was 31 people, which indicated that people in the village had a high interest in the development of science, particularly on agroforestry techniques.

The extension provided an understanding of the basic concepts of agroforestry for land rehabilitation, benefit of agroforestry in increasing income, and the types of forest peatland crops and agricultural crops to be developed.

\section{Agroforestry Demonstration Plots}

The implementation of agroforestry demonstration plots with agroforestry techniques developed on peatland in Sabaru Village, Palangka Raya, for 3 months can be said to be successful. A total of 200 forest and perennial crop seedlings showed high survival percentage at $90 \%$, while the agricultural crops showed no results yet because they were newly planted within 2-3 weeks (Table 1). 
Table 1 Survival Percentage of Crops in Agroforestry Demonstration Plots, Sabaru Village, Palangka Raya

\begin{tabular}{|c|c|c|c|c|}
\hline No & Crop Types & $\begin{array}{c}\text { Number of } \\
\text { crops planted } \\
\text { (stems) }\end{array}$ & Living Crops & $\begin{array}{c}\text { Survival } \\
\text { Percentage } \\
(\%)\end{array}$ \\
\hline & Forest and Perennial Crops (3 months) & & & \\
\hline 1 & Meranti & 100 & 90 & 90 \\
\hline 2 & Petai & 60 & 50 & 84 \\
\hline 3 & Rambutan & 20 & 18 & 88 \\
\hline \multirow[t]{3}{*}{4} & Mango & 20 & 20 & 100 \\
\hline & Total & 200 & 178 & 90 \\
\hline & Agricultural and Versatile Crops & & & \\
\hline 1 & Cayenne pepper & 30 & 10 & 33 \\
\hline 2 & Okra & $-*$ & - & - \\
\hline 3. & Lemongrass & 30 & 30 & 100 \\
\hline 4. & Red ginger & 30 & - & $* *$ \\
\hline 5. & Kencur & 30 & - & ** \\
\hline 6. & Turmeric & 30 & - & ** \\
\hline
\end{tabular}

Notes: ${ }^{*}$ still in nursery

** not yet productive (crop age of 3 weeks)

The planting patterns of agroforestry demonstration plot technique were started by preparing the planting paths for the types of forest crop 'meranti' and perennial crops petai, mango and rambutan, as well as the planting paths for agricultural and versatile crops between the paths of forest crops. However, at the time this activity was conducted, the new agricultural crop planting was carried out only in some arrays between planting paths to ensure its success given the planting location that could be inundated during rainy season, and dry in dry season. The forest and perennial crops were planted by making higher planting mounds, while agricultural and versatile crops were planted by making the soil mound along the array to ensure the crops were not inundated during the rainy season. More details about planting patterns of agroforestry demonstration plots are presented in Figure 1.

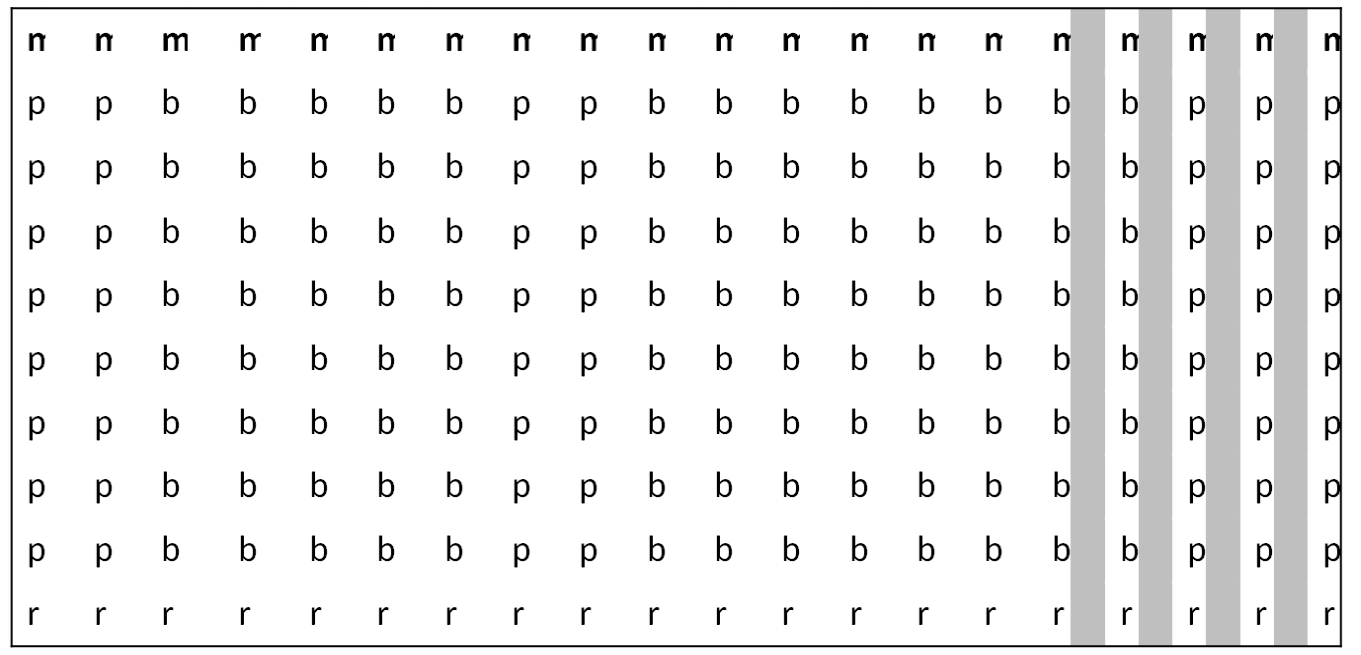

Keterangan :

$\square=$ Array of agricultural crop (cayenne pepper, okra) and versatile crops (red ginger, tutmeric, lemongrass, kencur)

$\mathrm{m}=$ mango, $\mathrm{p}=$ petai, $\mathrm{r}=$ rambutan, dan $\mathrm{b}=$ belangeran

Spacing between forest and perennial crops $=5 \times 5 \mathrm{~m}$

Figure 1 Planting Patterns of Agroforestry Technology on the Agroforestry Demonstration Plots in Sabaru Village 
The planting pattern of fruit trees (mango and rambutan) served as the barrier for the demonstration plots. Petai trees, the legume crops planted among meranti trees, were intended to give positive effects in the long term on improving soil fertility.

The obstacles encountered in the implementation of agroforestry demonstration plot preparation were the lack of understanding of the need for timberproducing forest crops (e.g. meranti) in home gardens or agricultural lands for wood supply, and the increasing scarcity of meranti. The community interest in planting typical peatland crops was very low. For the community, meranti was not suitable to be planted in home gardens or yards because they thought meranti should grow only in forest and when planted in the garden it could reduce the aesthetic. Planting meranti just wasted the space of the land in the gardens or yards. This is in contrast to the Javanese community who plant teak trees to produce timber. They also plant the teak trees in their home gardens or yards with the intention of "saving", shade, and at the same time improving the quality of the lands.

\section{CONCLUSIONS AND SUGGESTIONS}

The public response was quite high to the extension activity but low to the training activity. It can be seen from the number of the extension programs carried out that were more than what had been planned. Meanwhile, the training and establishment of agroforestry demonstration plots were not as much as the extension programs.

Agroforestry demonstration plots are expected to be the examples that can be carried out on other unproductive or degraded lands, thus improving the environmental functions and people's income.

It is necessary to provide an approach that encourages people to look ahead the issues that need to be addressed, such as the increasing need for timber while the supply is less, and or to participate in the conservation of typical peatland crop type meranti which is increasingly scarce.

\section{REFERENCES}

Foresta, H. De \& G. Michon (2000). Indonesian Agroforestry: Different System Different Approach. In
Typical Indonesian Agroforestry. ICRAF.

Matatula, J. (2009). Rehabilitation Measures of Degraded Lands by Implementing Agroforestry Technology of Silvopastoral System in Oebola Village, Fatuleu Subdistrict, Kupang Regency. Inotek 13 (1).

Simon, H. (1994). Forest Development Planning for Social Forest Strategy. Foundation Center for the Study of Forest Resources. Yogyakarta.

Walhi (2015). Environmental Review 2015. The Indonesian Forum for Environment. Jakarta. Retrieved from http://www.walhi.or.id/wpcontent/uploads/2015/01/OutLook 2015_Final.pdf

Widianto, Hairiah, K., Suharjito, D. \& Sardjono, M.A. (2003). Functions and Roles of Agroforestry. World Agroforestry Centre (ICRAF) Southeast Asia Regional Office PO Box 161 Bogor, Indonesia. 